\title{
Management of Hydrallantois by Transcervical Allantocentesis Along with Medical Termination of Pregnancy: A Report of 7 Clinical Cases
}

\author{
S. Manokaran ${ }^{1 *}$, M. Palanisamy ${ }^{2}$, M. Selvaraju ${ }^{3}$, R. Ezakial Napolean ${ }^{4}$, \\ N.V. Kavithaa ${ }^{5}$ and T. Geetha ${ }^{6}$ \\ ${ }^{1}$ Kangayam Cattle Research Station, Uppupallam, Baguthampalayam, \\ Sathyamangalam - 638 451, India \\ ${ }^{2}$ Department of Veterinary Gynecology and Obstetrics, Veterinary College and Research \\ Institute, Orathanadu - 614 625, India \\ ${ }^{3}$ Department of Veterinary Gynecology and Obstetrics, Veterinary College and Research \\ Institute, Namakkal - 637 002, India \\ ${ }^{4}$ Department of Clinics, Veterinary College and Research Institute, \\ Namakkal - 637 002, India \\ ${ }^{5}$ Kangayam Cattle Research Station, Uppupallam, Baguthampalayam, \\ Sathyamangalam - 638 451, India \\ ${ }^{6}$ Veterinary University and Training Centre, Veterinary Hospital campus, \\ Kamarajarsalai, Tiruppur - 648 604, India \\ *Corresponding author
}

\section{A B S T R A C T}

\begin{tabular}{l}
\hline Ke y w o r d s \\
Hydrallantois, \\
Transcervical \\
allantocentesis, \\
Rusch catheter, \\
Medical \\
termination, \\
Allantoic fluid, \\
Retained placenta \\
\hline Article Info \\
\hline $\begin{array}{l}\text { Accepted: } \\
22 \text { March } 2020 \\
\text { Available Online: } \\
10 \text { April } 2020\end{array}$ \\
\hline
\end{tabular}

The present investigation was carried out to assess the efficacy of novel transcervical allantocentesis to drain allantoic fluid along with medical termination of pregnancy to treat hydrallantois affected cows. A total of seven crossbred cows were treated by this method. All the cows had clinical signs like severe bilaterally distended abdomen, respiratory distress, expiratory grunt and difficulty in walking during admission due to excessive allantoic fluid accumulation. The transcervical allantocentesis was performed using Rusch catheter (18") by fixing the catheter at internal os of cervix after passing through the allantoic membrane. Simultaneously the induction of parturition was done using inj. Cloprostenol $(500 \mu \mathrm{g}, \mathrm{i} / \mathrm{m})$ and inj. Dexamethasone $(24 \mathrm{mg}, \mathrm{i} / \mathrm{m})$. The average allantoic fluid drained from all the 7 animals was $91.72 \pm 6.48$ litres with an average drainage rate of $3.17 \pm 0.15$ litres per hour. The time taken for the drainage of the allantoic fluid was $28.94 \pm 2.58$ hours. The time interval between the medical termination and delivery of the fetus was $50.50 \pm 10.91$ hours. Out of 7 cows, in 6 cows the fetus was removed manually and in one cow cesarean section was performed. All the cows were treated for retained placenta after removal of the fetus. From the study it was concluded that transcervical allantocentesis could be used along with medical termination of pregnancy to treat hydrallantois to save the dam. 


\section{Introduction}

Hydrallantois or hydrops of allantois is a sporadic gestational disorder noticed in dairy animals (Roberts, 1971). Hydrallantois is characterized by sudden bilateral distension of abdomen due to rapid accumulation of watery, amber colored fluid inside the allantoic cavity over a period of 5 to 20 days in late gestation and is always giving suspicion for twin or triplet pregnancy (Morrow, 1986; Drivers and Peek, 2008). Roberts (1971) stated that this pathological dropy condition usually affects both fetus and fetal membranes and accounts for about 80 to 90 percent of dropsical condition (Roberts, 1971). Hydrallantois is usually related with a diseased uterus. In diseased uterus most of the caruncles in one horn are not functional and the remaining placentomes are enlarged and possibly diseased (Drost, 2007). The physiopathology of this condition is associated with the reduction in vascularization of placenta resulting in metabolic changes in the placental tissue and fetal membranes which leads to accumulation of fetal fluids (Kapadiya et al., 2018). Apart from this, fetal malformation, fetal hepatic disorders, fetal renal disorders and torsion of umbilical cord are also causes hydrallantois (Jackson, 2006; Landim-Alvarenga, 2006).

If early diagnosis and treatment of hydrallantois is not done, in advanced conditions the animal would be unable to rise and the prognosis will be hopeless. Medical termination of pregnancy with prostaglandin $\mathrm{F}_{2} \alpha$ and corticosteroidsis usually followed for the treatment of this condition (Manokaran et al., 2011) but the sudden removal of allantoic fluid following medical termination leads to hypovolemic shock and collapse of the animal (Peiro et al., 2007). The slow and continuous removal of allantoic fluid may be an alternative method to avoid shock to the animal (Noakes et al., 2009). Transcervical allantocentesis is a method of treatment that can be used along with medical termination of pregnancy to treat hydrallantois cases (Manokaranet al., 2016). The transcervical allantocentesis will help in slow and continuous release of allantoic fluid and thereby the respiratory distress and hypovolemic shock can be avoided in dam. The medical termination will help in cervical dilatation and expulsion of fetus. The transcervical allantocentesis was tried in 7 crossbred cows which were brought to VCC, VCRI, Namakkal with the history of hydrallantois. The present study reports the effectiveness of the novel transcervical allantocentesis along with prostaglandin $\mathrm{F}_{2} \alpha$ and dexamethasone treatment in crossbred cows with hydrallantois.

\section{Materials and Methods}

Seven crossbred cows affected with hydrallantois which were brought to VCC, VCRI, Namakkal for treatment were utilized for the study. All these cows were belonging to different farmers and were presented with the history of i). 6 to 8 month of gestation, ii). sudden bilateral distension within 7-12 days, iii). anorexia iv). lack of rumination, v). respiratory distress, vi). expiratory grunt and vii). difficulty in getting up and walking. The animals were examined clinically to rule out cause(s) for sudden distension of abdomen.

\section{Reproductive tract examination}

The cows were examined clinically in a routine manner including rectal and vaginal examination. In all the animals, the vaginal examination revealed a patent vaginal passage with closed external os of cervix.The rectal examination revealed a highly distended and fluid filled uterus which was obliterating towards the pelvic cavity. The fluid filled uterus was occupying the entire pelvic and abdominal cavity. The fetal parts were not 
palpable in all the animals; the fremitus was very sluggish. The placentomes were also not palpable. Based on the history, clinical, rectal and vaginal examination, the cases were diagnosed as hydrallantois.

\section{Treatment regimen followed}

It was decided to terminate the pregnancy with prostaglandin $\mathrm{F}_{2} \alpha$ and corticosteroids to save the dam. But during cervical dilatation (which occurs after medical termination) the excessively accumulated allantoic fluid if gushes out suddenly, the dams may collapse due to hypovolemic shock. All the animals had bilaterally distended abdomen and severe respiratory distress due to excessive accumulation of the fluid in the allantoic cavity. Hence it was decided to relieve the allantoic fluid slowly over a period of time to relive the pressure exerted over the abdominal and thoracic cavity due to fluid accumulation in the allantoic cavity and also to avoid hypovolemic shock due to sudden release of fluid after cervical dilatation. To withdraw the allantoic fluid slowly, it was decided to do transcervical allantocentesis. For this, Rusch catheter (18") was inserted into the plunger of artificial insemination gun and passed through vagina and fixed at the level of internal os of cervix by piercing allantoic bag. The balloon of the Rush catheter was inflated with $10 \mathrm{ml}$ air. The allantoic fluid was slowly and continuously passed out through the Rusch catheter (Figure 1) and it was collected in vessels for measurement. At the same time, the parturition was induced with inj. Cloprostenol (500 $\mu \mathrm{g}, \mathrm{i} / \mathrm{m})$ and inj. Dexamethasone (24 mg, i/m) (Manokaran, 2005 and Manokaran et al., 2011). The animals were clinically treated with inj. Streptopenicillin (5 gm, I/M), inj. Analgin (20 $\mathrm{ml}, \mathrm{I} / \mathrm{M})$ and inj. Chlorpheniramine maleate (100 mg, I/M). To compensate the fluid loss, the intravenous fluid (inj. Normal saline - 10 liters) was administered in the morning and evening. The treatment was continued for two days. Vaginal examination was carried out once in 12 hours to assess the cervical dilatation. The cervical dilatation occurred in 6 animals and the fetuses were removed manually in all these animals. In one animal (cow No.: 3), the cervical dilatation was not complete and the cesarean section was performed as per the standard procedure to remove the fetus.

\section{Examination of the fetus}

In all the cases the fetuses were dead. The necropsy of the fetus revealed enlarged fetal kidneys with hydronephrotic changes. The other internal organs were normal. The fetal kidneys were subjected to histopathological examination.

\section{Results and Discussion}

The details of animal presented with summary of the clinical signs observed are presented in table 1. The observations indicated that the hydrallantoismostly occurs during late second trimester or during third trimester of pregnancy i.e. between 6-8 month of gestation. All the animals presented were previously calved. Out of the 7 animals, three animals (42.86\%) had complications during previous calving.

The other symptoms exhibited were sudden bilateral distension of abdomen, anorexia, lack of rumination, respiratory distress, expiratory grunt, difficulty in getting up and constipation which were in accordance with the observations made by Kumar et al., (2016), Kapadiya et al., (2018) and Sathish et al., (2019). Kapadiya et al., (2018) reported that sudden accumulation of allantoic fluid might produce excess pressure on diaphragm leading to respiratory distress and expiratory grunt as observed in the present case. 
The clinical observations made after transcervical allantocentesis with induction of parturition in treated cows were presented in table 2 . The average allantoic fluid volume drained through transcervical allantocentesis from all the seven animals presented for treatment was $91.72 \pm 6.48$ litres with a range of 81.70 to 99.40 litres. In accordance to this study Palanisamy et al., (2014) has observed a volume of 90-100 litres of allantoic fluid in hydrallantois affected non-descript buffalo whereas Manokaran et al., (2016) has observed 121 litres of allantoic fluid in a Jersey crossbred cow affected with hydrallantois which was slightly higher than volume noted in this study. When compared to this study, a volume of 110, 140, 250-272 litres of allantoic fluid volume was expelled from buffaloes in observations made by Kumar et al., (2016), Kumar et al., (2012) and Kapadiya et al., (2018), respectively. After removal of the fluid the abdominal size got reduced greatly (Figure 2) and respiratory distress was absent as observed by Manokaran et al., (2016).

The average allantoic fluid volume drained through the Rusch catheter in transcervical allantocentesis was $3.17 \pm 0.15$ litres per hour and the time taken for the complete drainage of the fluid through Rusch catheter was $28.94 \pm 2.58$ hours in the reported cases. Similar to this study, Kumar et al., (2016) drained the allantoic fluid slowly (2.08 litres per hour) in buffaloes. But Kapadiya et al., (2019) has drained 250 to 272 litres of fluid from the allantoic sac over a period of 2 to 3 hours by puncturing allantoicsac manually per vaginum. Purohit and Gaur (2011) opined that sudden expulsion of allantoic fluid invariably results in hypovolaemic shock. Peiro et al., (2007) reported that escaping of large volume of allantoic fluid rapidly from the uterus may develop circulatory hypovolemic shock. Napolean et al., (2012) reported that Rusch catheter might be used to drain the allantoic fluid slowly to prevent hypovolemic shock. In the present study slow draining of allantoic fluid was carried out through Rusch catheter by transcervical allantocentesis. Further the continuous fluid replacement along with slow withdrawal of fluid might be the reason for the non-occurrence of hypovolemic shock in all the reported cases.

The time taken for the complete cervical dilatation after induction and delivery of the fetus was 50.50 \pm 10.91 hours. In accordance with this study, Pandey et al., (2014) has recorded a time interval of $44.32 \pm 1.71$ hours between termination and delivery of the fetus. Shukla et al., (2008) reported that combination of prostaglandin $\mathrm{F}_{2} \alpha$ and dexamethasone would be more effective for termination of pregnancy when compared to use of the either drugs alone. The less duration of time taken between induction and calving in this study might be due to the synergistic action of the drugs as described.

Out of the seven cases studied, in one case (cow 3) the cervix was not dilated even after 72 hours of medical termination and the cesarean section was performed to deliver the fetus. Rangasamy et al., (2013) reported that the cervical dilatation was not occurred in a non-descript cow affected with hydrallantois even after two prostaglandin $\mathrm{F}_{2} \alpha$ and dexamethasone injection at 72 hours interval and performed cesarean section on $5^{\text {th }}$ day. If cervical dilatation has not occurred after termination of pregnancy, the cesarean section would be the only option to deliver the fetus in hydrallantois cases (Arthur et al., 1989).

In all the cases the fetuses were removed manually after the cervical dilation. Pandey et al., (2014) reported an incidence of $54.54 \%$ dystocia after treatment for hydrallantois. Zaborski et al., (2009) opined that the overstretching of the uterine musculature 
would be reason for the dystocia after cervical dilation. Barter (1986) reported that the parturition was abnormal in hydrallantois affected animals because of incomplete cervical dilatation with primary uterine inertia and lack of strong abdominal contractions.

All the animals were treated for retained placenta after the delivery of the fetus in the reported cases. This was in accordance with the findings of Pandey et al., (2014). On examination the placenta was hard, leathery, thickened and gelatinous. It was necrosed in few places and hypertrophied in some areas. It might be due to disease of uterus and placenta (Roberts, 1971 and Napolean et al., 2012).

Table.1 Summary of the cases affected with hydrallantois

\begin{tabular}{|c|c|c|c|c|c|c|c|}
\hline $\begin{array}{l}\text { Cow No. } \\
\text { Details }\end{array}$ & Cow 1 & Cow 2 & Cow 3 & Cow 4 & Cow 5 & Cow 6 & Cow 7 \\
\hline Breed & $\begin{array}{c}\text { HF } \\
\text { crossbred }\end{array}$ & $\begin{array}{c}\text { HF } \\
\text { crossbred }\end{array}$ & $\begin{array}{l}\text { Jersey } \\
\text { crossbred }\end{array}$ & $\begin{array}{c}\text { HF } \\
\text { crossbred }\end{array}$ & $\begin{array}{c}\text { HF } \\
\text { crossbred }\end{array}$ & $\begin{array}{c}\text { HF } \\
\text { crossbred }\end{array}$ & $\begin{array}{c}\text { Jersey } \\
\text { crossbred }\end{array}$ \\
\hline Gestation & 7 months & $\begin{array}{l}6 \text { and half } \\
\text { months }\end{array}$ & 8 months & $\begin{array}{l}7 \text { months } \\
\text { and } 12 \\
\text { days }\end{array}$ & 7 months & $\begin{array}{l}7 \text { and half } \\
\text { months }\end{array}$ & 6 months \\
\hline $\begin{array}{l}\text { No. of } \\
\text { previous } \\
\text { calving }\end{array}$ & 3 & 2 & 3 & 5 & 4 & 3 & 5 \\
\hline $\begin{array}{l}\text { History of } \\
\text { previous } \\
\text { calving }\end{array}$ & Normal & $\begin{array}{l}\text { Dystocia } \\
\text { with } \\
\text { retained } \\
\text { placenta }\end{array}$ & Normal & $\begin{array}{l}\text { Retained } \\
\text { placenta }\end{array}$ & $\begin{array}{l}\text { Retained } \\
\text { placenta }\end{array}$ & Normal & Normal \\
\hline $\begin{array}{l}\text { Sudden } \\
\text { bilateral } \\
\text { distension of } \\
\text { abdomen }\end{array}$ & $\checkmark$ & $\checkmark$ & $\checkmark$ & $\checkmark$ & $\checkmark$ & $\checkmark$ & $\checkmark$ \\
\hline Anorexia & $\checkmark$ & $\checkmark$ & $\checkmark$ & $\checkmark$ & $\checkmark$ & $\checkmark$ & $\checkmark$ \\
\hline $\begin{array}{l}\text { Lack of } \\
\text { rumination }\end{array}$ & $\checkmark$ & $\checkmark$ & - & $\checkmark$ & $\checkmark$ & $\checkmark$ & $\checkmark$ \\
\hline $\begin{array}{l}\text { Respiratory } \\
\text { distress }\end{array}$ & $\checkmark$ & $\checkmark$ & $\checkmark$ & $\checkmark$ & $\checkmark$ & $\checkmark$ & $\checkmark$ \\
\hline $\begin{array}{l}\text { Expiratory } \\
\text { grunt }\end{array}$ & $\checkmark$ & $\checkmark$ & - & $\checkmark$ & $\checkmark$ & - & $\checkmark$ \\
\hline $\begin{array}{l}\text { Difficulty in } \\
\text { getting up }\end{array}$ & $\checkmark$ & $\checkmark$ & $\checkmark$ & $\checkmark$ & $\checkmark$ & $\checkmark$ & $\checkmark$ \\
\hline Constipation & $\checkmark$ & - & - & - & $\checkmark$ & $\checkmark$ & $\checkmark$ \\
\hline
\end{tabular}


Table.2 Clinical findings after transcervical allantocentesis with induction of parturition in treated cows

\begin{tabular}{|c|c|c|c|c|}
\hline Details & $\begin{array}{c}\text { Average allantoic } \\
\text { fluid volume drained } \\
\text { (litre) }\end{array}$ & $\begin{array}{c}\text { Average } \\
\text { allantoic fluid } \\
\text { drainage per } \\
\text { hour (litre) }\end{array}$ & $\begin{array}{l}\text { Time taken for } \\
\text { drainage (hours) }\end{array}$ & $\begin{array}{l}\text { Average time } \\
\text { taken for } \\
\text { cervical } \\
\text { dilatation and } \\
\text { delivery of the } \\
\text { fetus (hours) }\end{array}$ \\
\hline Cow 1 & 86.60 & 3.28 & 26.40 & 60 \\
\hline Cow 2 & 81.70 & 3.19 & 25.60 & 52 \\
\hline Cow 3 & 99.40 & 3.07 & 32.30 & Caesarean section \\
\hline Cow 4 & 98.50 & 3.37 & 29.20 & 64 \\
\hline Cow 5 & 90.60 & 2.99 & 30.30 & 51 \\
\hline Cow 6 & 89.70 & 3.28 & 27.30 & 40 \\
\hline Cow 7 & 95.60 & 3.03 & 31.50 & 36 \\
\hline Mean \pm SE & $91.72 \pm 6.48$ & $3.17 \pm 0.15$ & $28.94 \pm 2.58$ & $50.50 \pm 10.91$ \\
\hline
\end{tabular}

Figure.1 Slow and continuous release of allantoic fluid through Rusch catheter (transcervical allantocentesis)

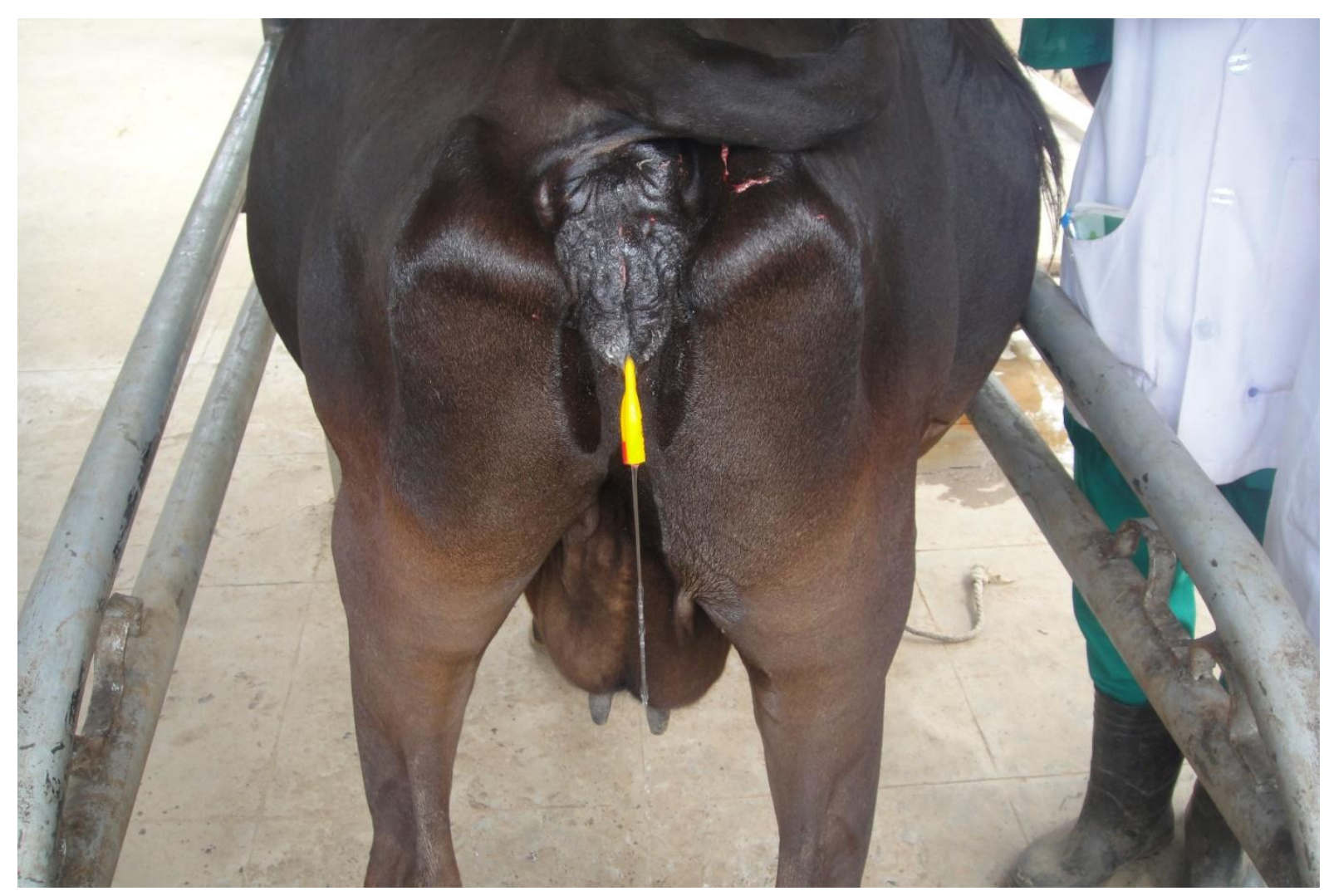


Figure.2 Cow after transcervical allantocentesis - the abdominal size was reduced

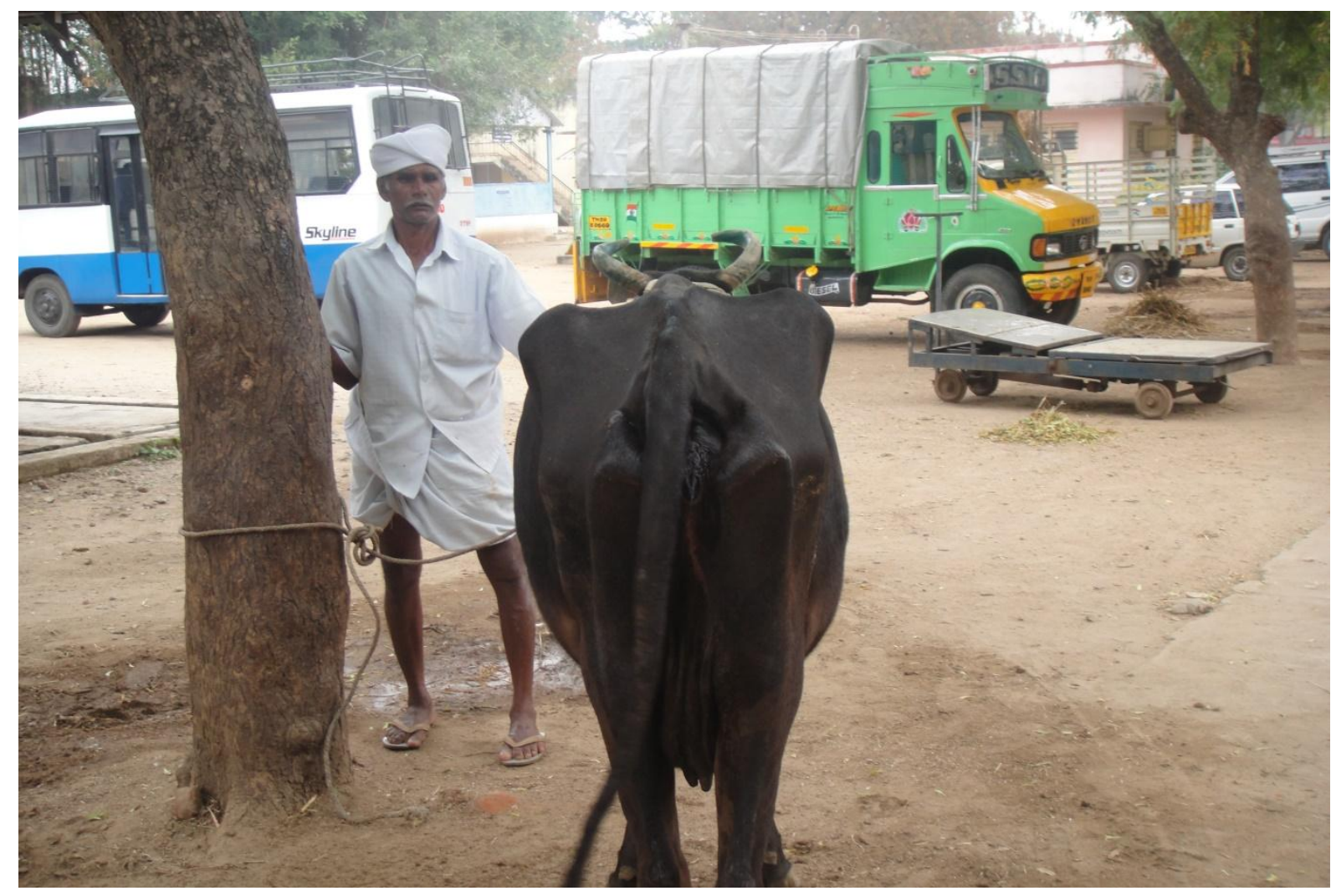

Figure.3 Enlarged fetal kidneys with hydronephrotic changes

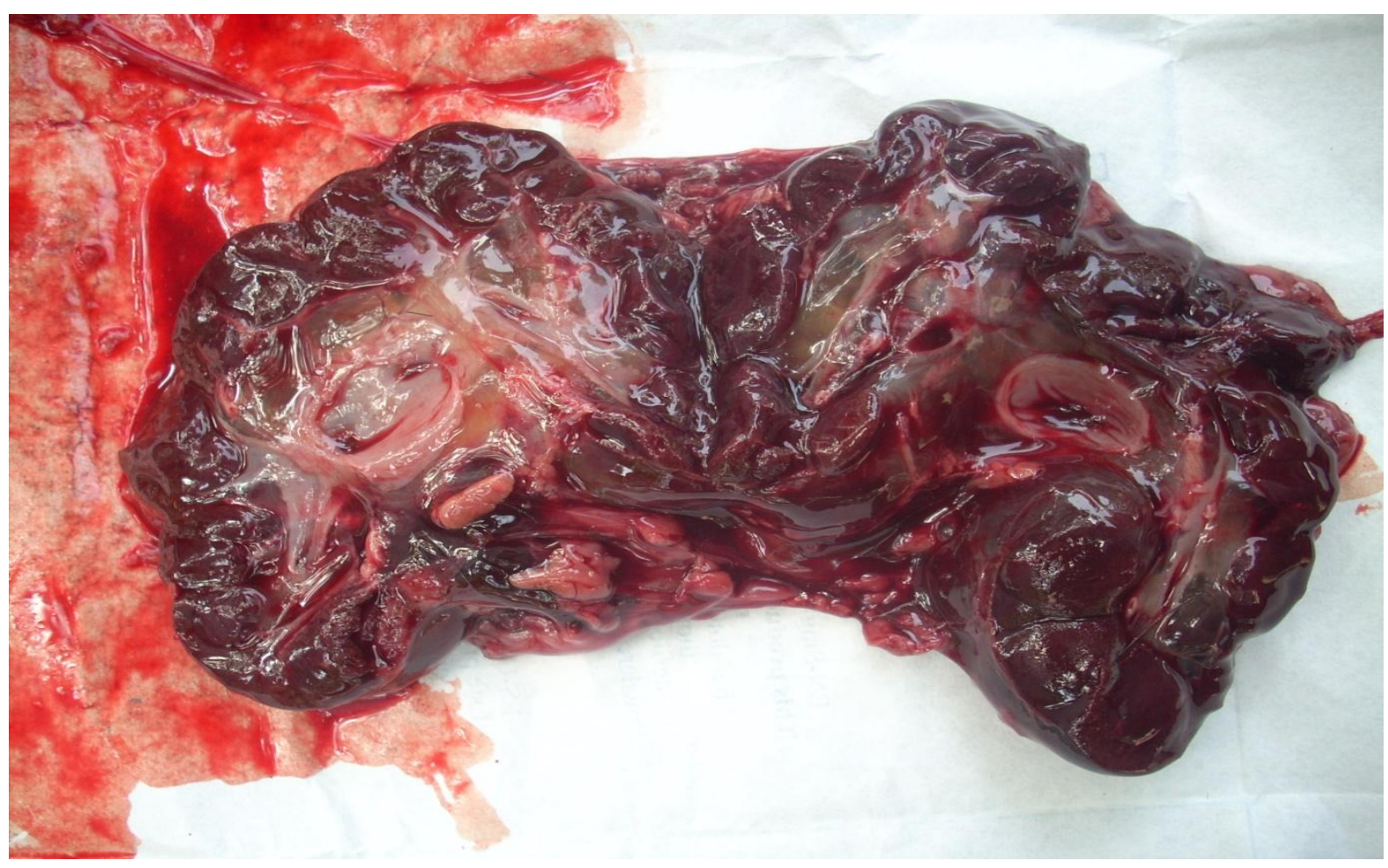


Figure.4 Distended kidney tubules without cuboidal epithelium

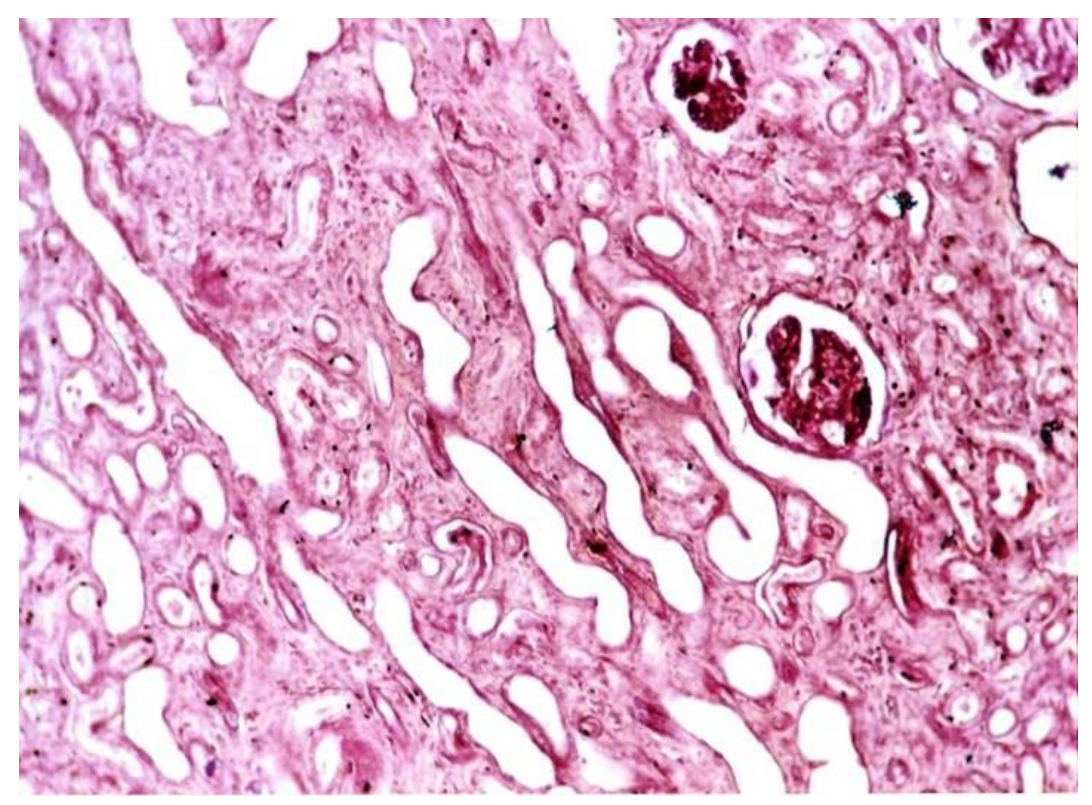

The histopathological examination of the fetal kidneys was carried out to rule out the hydronephrosis. In all the seven cases, the fetal kidneys were enlarged and it was able to visualize the hydronephrotic changes on gross examination (Figure 3). On histopathological examination, the kidney tubules were distended and were without cuboidal epithelium which confirms the hydronehrosis (Figure 4). The hydronephrosis of fetal kidney could result in polyurea, which might be the reason for excessive accumulation of fluid inside the allantoic cavity (Palanisamy et al., 2014).

From the above study it was concluded that

Hydrallantois mostly occurs between 6-8 months of gestation

Transcervical allantocenetsis can be effectively used along with medical termination of pregnancy with prostaglandin $F_{2} \alpha$ and dexamethasone in hydrallantois affected cases at least to save the dam

The slow and continuous removal of allantoic fluid through Rusch catheter during allantocentesis will reduce the respiratory distress and will prevent the hypovolemic shock in the affected animals

Simultaneous intravenous fluids during allantocentesis will be helpful to stabilize the dam

Manual removal of fetus is essential because of uterine inertia caused byover stretching of uterus due toexcessive allantoic fluid.

Fetal hydronephrosis which was observed in kidneys of the fetuses removed might be one of the major cause for hydrallantois.

\section{References}

Arthur, G.H., D.E. Noakes and Pearson H. 1989. Veterinary Reproduction and Obstetrics, ELBS Publishers, pp: 118-120.

Barter, A.D., 1986. Induced abortion in cattle. In: Marrow, D. A. (Ed.). Current Therapy in Theriogenology. W.B. Saunders Co., Philadelphia, USA, pp: 586.

Drivers, T.J., and Peek, S. 2008. Rebhun's diseases of dairy cattle. $2^{\text {nd }}$ Eds., Saunders Elsevier, St. Louis, Missouri, pp: 395.

Drost, M., 2007.Complications during gestation in the cow. Theriogenology. 68: 487-491

Jackson, P.G.G., 2006. Problemas da gestacao. In: Jackson, P.G.G. (Ed.), Obstetricia Veterinaria, $2^{\text {nd }} E d n$., Sao Paulo, pp: 17-41. 
Kapadiya, P.S., S.S. Parikh, P.M. Chauhan, T.V. Sutaria and Nakhasi, H.C. 2018. Management of hydroallantois in a Jaffrabadi buffalo: A case report. Journal of Pharmacognosy and Phytochemistry. SP1: 1534-1536.

Kumar, S., U. Sharma, A.K. Pandey, S. Agrawal, R.B. Kushwaha and Tripathi, A.K. 2012. Hydroallantois in buffalo: A case report. Buffalo Bulletin. 31(2): 67-69.

Kumar, S., G.N. Purohit, J.S. Mehta and Yogesh, S. 2016. Hydroallantois in a buffalo with fetal anasarca. Buffalo Bulletin. 35(4): 517520.

Landim-alvarenga F., 2006. Problemas da gestacao.In: Prestes, N.C., and LandimAlvarenga, F. (Eds), Obstetrícia Veterinaria. $1^{\text {st }}$ Edn., Rio de Janeiro, pp: 130-158.

Manokaran, S., K. Ravikumar, R.E. Napolean, M. Palanisamy and Selvaraju, M. 2011. Hydrallantois in a non-descript buffalo: A case report. The Indian Journal of Field Veterinarians. 7: 69-70

Manokaran, S, R.E. Napolean, M. Palanisamy, M. Selvaraju and Prakash S. 2016. Clinical management of hydrallantois in a cow using transcervical allantocentesis method: A case report. International Journal of Science, Environment and Technology. 5(4): 1888-1892.

Morrow, D.A. 1986.Current Therapy in Theriogenology. W.B. Saunders Co., Philadelphia, USA, pp: 207-208.

Napolean, R.E., M. Palanisamy, M. Selvaraju and Manokaran, S. 2012. Successful management of hydroallantois in a Jersey crossbred cow. International Journal of Livestock Research. 2: 213-216

Noakes, D.E., T.J. Parkinson and England, G.C.W. 2009.Veterinary Reproduction and Obstetrics. $9^{\text {th }}$ Edn., Saunders Elsevier,
China, pp: 141-142.

Palanisamy, M., S. Manokaran and Selvaraju, M. 2014.Therapeutic management of hydroallantois in a buffalo. IntasPolivet. 15(2): 219-220.

Pandey, A.K., G. Singh, S. Kumar, K. Kumar and Luthra, R.A. 2014. Therapeutic management of hydrallantois: A report of 22 buffaloes. IntasPolivet, 15(II): 211-214.

Peiro, J.R., A.S. Borges, R. Yanaka, M.B. Koivisto and Mendes, L.C.N. 2007. Hydrallantois in an ewe (Case report). ArsVeterinaria. 23: 116-119.

Purohit, G.N. and Gaur, M. 2011. Etiology, antenatal diagnosis and therapy of fetal complications of gestation in large and small domestic ruminants. Theriogenology Insight. 2: 45-63.

Rangasamy, S., R.C. Rajasundaram, T. Sathiamoorthy and Sarath, T. 2013.Management of hydroallantois in a non-descriptive cow. Indian Journal of Animal Reproduction. 34(2): 52-53.

Roberts, S.J. (1971). Veterinary Obstetrics and Genital Diseases. $2^{\text {nd }} E d n$., CBS Publishers and Distributors, New Delhi, India, pp: 776.

Satish, Dinesh, J., Surendar, S.N., Devender, K. and Mitesh, G. 2019. A rare case of hydroallantois in buffalo and arthrogryposis, evisceration of abdominal content from umbilicus in a calf: A case report Journal of Entomology and Zoology Studies, 7(1): 1469-1472.

Shukla, S.P., A. Pandey and Nema, S.P. 2008. Emergency induction of parturition in buffaloes. Buffalo Bulletin. 27: 148-149.

Zaborski, D., W. Grzesiak, I. Szatkowska, A. Dybus, M. Muszynska and Jedrzeiczak, M. 2009. Factors affecting dystocia in cattle. Reproduction in Domestic Animals. 44: 540-551.

\section{How to cite this article:}

Manokaran, S., M. Palanisamy, M. Selvaraju, R. Ezakial Napolean, N. V. Kavithaa and Geetha, T. 2020. Management of Hydrallantois by Transcervical Allantocentesis along with Medical Termination of Pregnancy: A Report of 7 Clinical Cases. Int.J.Curr.Microbiol.App.Sci. 9(04): 2962-2970. doi: https://doi.org/10.20546/ijcmas.2020.904.347 